\title{
THE EFFECTS OF ORGANIZATIONAL STRUCTURE ON THE PERFORMANCE OF ORGANIZATIONS
}

\author{
Sunday C. Eze, Adenike O. Bello and Anthony T. Adekola \\ Department of Business Admininstration \\ Landmark University, Omu-aran, Kwara State. \\ Email: bello.adenike@lmu.edu.ng
}

\begin{abstract}
An organization can be likened to a building whose strength is determined by the structure and frames which holds it. The structure is the manner in which interrelated elements (resources) are arranged so that the building can be stable, resist stress and it provides the right form. To this end, for the performance of an organization to be effective, it is important to understand the right manner in which interrelated elements (structure) in the specific organization is arranged. To measure the performance of the organization, dependent variables such as sales, profit, and customer satisfaction will be considered. Also, the study utilized independent variables centralization and formalization organizational structures. This is to show the effects of the dependent variables on the independent variable. The research adopted quantitative design and applied mono method which brought about numerical data generated from questionnaire administered. The population of this study comprises of all staff of Covenant Micro Finance Bank as well as the customers of the banks. Total sum of 354 sample size comprising of both employees (51) and customers (303) of Covenant Micro Finance Bank is the sample size. The propositions assumed for this study are that: there is no relationship between organizational centralization and organizational customer satisfaction, there is no relationship between organizational centralization and organizational profit, there is no relationship between organizational formalization and organizational customer satisfaction and that there is no relationship between organizational formalization and organizational profit. Also, among the secondary data collected are views of various management researchers. As a result of the primary and secondary data collected, the study recommends that organizations should adopt decentralization structure and reduce formalization in the work place.
\end{abstract}

KEYWORDS: organization, organizational performance, organizational structure, decentralization, formalization.

\section{INTRODUCTION}

Organizational structure holds an important role on the performance of an organization. Therefore any one managing an organization must understand the importance of structuring an organization. There are various studies associated with effects of organizational structure and organizational performance. To start with, organization, generally is a managerial function of organizing, that involve grouping of activities, establishing authority and responsibility relationship, coordinating different functional activities in pursuit of achieving 
overall organizational objective and goals, and delegation of authority." (Shafaee, Rahnama, Alaei A and Jasour (2012) Chegini M. G, Yousefi .S And Rastad (2013) agreed that productivity is very important for an organization and that the main goal of every organization is to ensure the highest means of productivity level. According to Chegini, et al (2013), they believe that performance is one of the most essential and major issues that all organizations face and that with productivity all organization benefit of all sources and facilities to achieve more advantages. Chegini, et al, (2013) stated in their work that many elements influence on organizational performance as well as organizational structure. With the above statement this means there are factors that make up the dimensions of organizational structure which would show the relationship between organizational structure and organizational performance. According to some researchers in their literature they have pointed out what these dimensions are and which also has constituted their organizational structure variables.

Scholars like (Chegini, et al, 2013; Rajaeepour, Azizollah, Mahmoud and Shokouhi, 2012; Teixeira, Koufteros, \& Peng,, 2012; Csaszar, Stephen, Arbor \& Michigan 2012) have all stated in their work what these dimensions are as regards to organizational structure some dimensions presented were the same while others presented were different.

In literature scholars have agreed that performance is a major issue in most organizations and in day to day activity of organizations around the world they use different organizational structure and from literature review it can structure include; Flat structure, Tall Structure, Matrix Structure, Divisional Structure, Geographical Structure, bureaucratic structure etc. These structures are expected to lead to different combination of effort and performance and utilization of resources. However existing evidence shows that organization that makes use of either same or different structure don't get same result. Also organizational structure is concluded in literature to be determined by various factors such as; size, environment strategy and technology. This results to the need to harmonize the variables presented by these scholars. And therefore this study is one that attempts at harmonizing the variables which will also constitute the measurement for the construct organizational structure and show the level of relationship to organizational performance.

\section{Statement of the Problem}

Evidence show that organization that makes use of certain structures cannot do without structuring their organization with an element or dimension or mixed dimensions and in the process of operating these dimensions with structure of the organization, organization ends up achieving different result. Literature also points to the fact that there is no absolute way to structure a business. Whether a particular structure is advantageous or disadvantageous for an organization depends on the type of business, the strategy, its target market and the style of the management. Therefore this study is bothered about these dimensions and it results reached, and it seeks to find out if these results reached are satisfactory enough to lead to better performance as dimensions such as; Formalization, Complexity, Centralization, Decentralizations of structures are operated within organizations. 
In this research two organizational structural would be looked into such as; centralization and formalization because of short time and low finance to carry out this research. Therefore for this reason the variables for this work are as follows and the relationship between them constitute the problem that follows; Centralization in most organization has not allowed for faster utilization of structure and improvement in customer satisfaction of an organization. Centralization in an organization does not affect the profit of an organization. Increase in organizational formalization has only shown no significance change in customer satisfaction regarding an organization. Increase in organization formalization does not seem to improve on organizational profit.

\section{Objective of the Study}

1. The broad objective of this study is to appraise Effects of organizational structure on organizational performance.

2. To determine if there is any relationship between organizational centralization and organizational customer satisfaction.

3. To determine if there is any relationship between organizational centralization and organizational profit.

4. To determine if there is a relationship between organizational formalization and organizational customer satisfaction.

5. To determine if there is any relationship between organizational formalization and organizational profit.

\section{Research Question}

1. Is there any relationship between organizational centralization and organizational customer satisfaction?

2. Is there any relationship between organizational centralization and organizational profit?

3. Is there any relationship between organizational formalization and organizational customer satisfaction?

4. Is there any relationship between organizational formalization and organizational profit

\section{Research Hypothesis}

The hypothesis for this study is given below as;

$\mathrm{H}_{0}$ There is no relationship between organizational centralization and organizational customer satisfaction.

$\mathrm{H}_{0}$ There is no relationship between organizational centralization and organizational profit.

$\mathrm{H}_{0}$ There is no relationship between organizational formalization and organizational customer satisfaction.

$\mathrm{H}_{0}$ There is no relationship between organizational formalization and organizational profit.

\section{Significance of Study}

The broad significance of this study is to show with evidence of result after researching that organizational structure is very important in achieving performance in any organization.

Furthermore the significance of this research involves three aspects which are that; it will be useful to the organization in that it would enable them critically look into structural issues 
that they might have taken for granted (e.g. the statement of their guiding principles). It will proffer an alternative solution to management on ways in which the organizational performance can be improved upon in order to achieve desired success. The study will contribute to the expansion of existing knowledge on this area of study. It would also provide useful reference points for future researchers and a sound basis for intellectual exercise. Furthermore, if the suggestion from this study are effectively put to use and success is achieved, it could be used to influence the change in positions in both private and public organizations. This research will also be relevant to business men and women or entrepreneurs just starting up their organization, as it would give them insight in knowing effects of organizational structure on the performance of their organization or firm.

\section{LITERATURE REVIEW}

According to Owolabi and Kingsley, (2007) an organization is a social set up, which has a boundary that separates it from its environment, pursues its own collective goals, and controls its own performance. For managers, the term organization implies a formalized intentional structure of roles positions. Blessing, (2008) refers to it as a social unit or a human grouping intentionally constructed and reconstructed.

\section{Nature of Organizational Structure}

Akande and Ojokuku, (2008) described organizational structure as a group of people occupying a formal structure of position to achieve a particular purpose. They are institutions that enable society to pursue goals that could not be achieved by individuals' action alone. An organization is generally defined as a structure of relationships to get work done. It is a social system involving interpersonal relationships. Nwugballa, (2011) was of the view that establishment of an organizational structure presupposes the absence of a sole-proprietorship. It also assumes a level of operation that requires the joint effort many persons to successfully execute. This underscores the need to specify the different tasks that should be carried out by different individual job (job descriptions), how it should be carried out (operating procedures), expected standards of performance, line of authority, etc., in order to avoid confusion and conflict. It also requires the relationships and interactions between jobs; system of integration and coordination that would ensure organizational cohesion and, effective and efficient operations. Simply put, organizational structure defines the formal division, grouping, and coordination of job tasks (Robbins, 2005).

As far as an organization is concerned structures of different forms exist, and it is the consciousness of creating and applying structure chosen that brings in changes in an organizations' output or performance. Every management has to establish its own organization structure for efficient handling of business activities. The term 'Organization structure' has become very important in the business world today, which in other words has also distinguished different organizations in the world. The word "organization" is gotten from the word 'organism' which means a structure of body divided into different parts that are held together by a fabric of relationship as one organic whole. 
Vol.5, No.6, pp.46-62, December 2017

Published by European Centre for Research Training and Development UK (www.eajournals.org)

Organizational Structure can be seen as the rules that oversee the relationship between individuals or teams who try to achieve the organizational goals. In an organization of any size or complexity, employees' responsibilities most often are defined by what they do, who they report to, and for managers, who reports to them. Also put differently by another scholar, kuye (2004) referred jones (1995), in his book, that organizational structure is the formal system of task and reporting relationships that determines how employees use resources to achieve organizational goals. With the above definition, it shows that organizational structure is essential for the conduct of business activities or relationships that exist in the organization like task and reporting activities or relationships which dedicates how employee use available resource effectively to bring about efficient result. Droege (2013) defined organizational structure as the way people and jobs are arranged so that work can be performed and its goals can be met. Adding that "When a work group is very small and face-to-face communication is frequent, formal structure may be unnecessary, but in a larger organization decisions have to be made about the delegation of various tasks. Thus, procedures are established that assign responsibilities for various functions. It is these decisions that determine the organizational structure." Organizational structure finds a way to ensure that information flows from a particular level to another level within the company. Muo \& Muo (2007) in their book cited Robert Duncan who defined organizational structure as "a pattern of interactions and co-ordinations that links technology, task and human components of the organization to ensure that the organization accomplishes its purpose". With the definition above given by various scholars this work finds out that organizational structure has to do with relationships between people, resources and levels in an organization, which makes structure very important for companies or businesses that wants to be productive in their day to day activities. These definitions points out the importance of structure in an organization; some of which are that it ensures optimum utilization of a nation's human resources or specialized workers from aboard, it facilitates coordination of different resources, gives room for division of work where possible, allows growth, expansion and diversification, and it stimulates creativity.

Chegini et al, 2013, pointed out their dimensions for organizational structure as complexity, formality and concentration. Rajaeepour et al, (2012) gave their dimension to be classified as mechanical structure and organic structure; and that for the mechanical structure it is classified as; complexity, high formality, centralization, programmed behaviour, and regulation and that organic structure is concerned with decentralization and flexible structure. Teixereira et al, (2012) saw dimension of organization as centralization, flatness of organization, specialization and horizontal integration. Csazar et al, (2012) rounded it to be centralization and decentralization. Naveed (2010), was of the view that dimension are classified as; specialization, formalization, centralization, hierarchy, breath of the span of control, length and width of the hierarchy which they and contextual as size, technology and environment. According to the work of Shafaee et al, (2012) Centralization refers to degree that decision making is concentrated at one unit point in organization. Power density at a point implies on concentration and lack of density or low density is a sign of decentralization. Concentration is the issue of distribution rate in powers decision making no geographical separation of organization. Concentration is the emphasis with formal organizational structure no with the informal organization and only used formal authority, focus look at 
decision-makers votes and comments. Organization will facilitate achieving the goals through group efforts coordination. Decision making and information processing are the key elements of coordination. Due to employee participation in decision-making process, decentralization in decision making is caused motivation (Robins, 2000). Centralization this considers where the position or point of decision-making lies. In some organizations, decision making is highly centralized. In other cases, decision making is decentralized. An organization is not either centralized or decentralized. These represent two extremes on a continuum. Organization tends to be centralized or decentralized. The placement of the organization on this continuum is one major factor in determining what type of structure exists (Enikanselu and Oyende, 2009).

Formalization is the degree to which rules and procedures are standardized and utilized. It means the degree to which the jobs within an organization are standardized of formalized. Where formalization is low, there will be wider use of discretion by employees subordinates.Formalization is defined as the extent of written procedures, instructions laws and communication. Formalization can be done within job or it be imposed from outside when formalization is determined from outside for job used terms of external behaviour for its. In this case rules and procedures are executed directly by the lower management that representing jobs that unskilled workers can do the job incumbent (Dehkordi, 2009). Formalization can be referred to as the maximum level to which an organization relies on rules and procedures in order to direct the behaviour of workers in the organization.

Richard et al, (2009) stated that "organizational performance encompasses three specific areas of firm outcomes: (a) financial performance (profits, return on assets, return on investment, etc.); (b) product market performance (sales, market share, etc.); and (c) shareholder return (total shareholder return, economic value added, etc.)".As seen in other literature on organizational performance, Ismael, Nor'Aini, and Davoud, (2010) performance is all about achieving the objectives that organizations/firms set for themselves. The objectives of an organization / firm could be financial, that is to say, profit-making or nonfinancial such as spreading awareness among a certain community etc. Organizational performance therefore could be categorized under two: financial and nonfinancial. The profitability of an organization is an important financial indicator to reflect the efficiency of the organization and the owners/managers ability to increase sales while keeping the variable costs down (Davis, Schoorman, Mayer,\&Tan 2000). Profit margin, return on assets, return on equity, return on investment, and return on sales are considered to be the common measures of financial profitability (Robinson, 1982; Galbraith \& Schendel, 1983). Ismael, Nor'Aini, and Davoud, (2010) organizational performance is widely measured through the financial success of the organization. Financial stress for most profit-oriented organization can be assessed both in terms of sales as well as profitability measures (Davis et al., 2000).

Other scholars Zani and Berzieri, (2008) argued that Customer Satisfaction is a key performance indicator of the activity of a firm or a corporation (Fornel, 2008). Mohammad, Shaeir, Shahram, Seyed and Seyyed, (2011) supported this view that "customer satisfaction and delight is presented as solid bedrock of bank longevity and profitability, and in their work they cited Keiningham, Perkins-Munn, Aksoy, and Estrin (2005), stating that "it is a 
significant affiliation between customer satisfaction, purchase intentions, and consequently financial performance". According to Armstrong and Kotler (2009) considered relationship marketing as a kind of index for customer satisfaction, and they believed that the maintenance of excellent relationship marketing between the enterprise and customers would be beneficial in increasing customer satisfaction. Ambro and Praprotnik, (2008) stated "Customer satisfaction is an organization's ability to attract and retain customers and to improve customer relationship over time". According to Karunaratne and Jayawardena, (2010) Customer satisfaction has become a key performance indicator for the hotel business.

Mohammad and Shahzad, (2012) customer satisfaction is depended on perceived quality and perceived value. Every firm in the competitive market struggles to maximize their profits. So they can maximize their profitability by providing attractive products and services to their customers. Ambro and Praprotnik, (2008) defined Customer satisfaction as the outcome of his or her needs and expectations which influence the interaction with service providers and other customers. The quality of this interaction impacts customer decisions to repurchase the service, his retention and the intention of the customer to recommend to other potential customers and finally to pass on useful information about the service quality and delivery. The higher or lower satisfaction of a consumer will depends upon the quality of brand characteristics that offered by a company (Gerpott, Rams and Schindler, 2001). To ensure retention of consumer, it is important to satisfy consumers (Guo, Xiao and Tang, 2009). That is when there is low quality services customers are not satisfied and this will lead to low performance in the organization. Service is an important element for consumer satisfaction but this is not to say that it is the only element which is responsible (Lin and $\mathrm{Wu}, 2011$ ).

\section{THEORETICAL FRAMEWORKS}

The study will consider Weber's Way of Bureaucracy and Taylor's scientific management theories. Max Weber believed that an ideal bureaucracy has to do with six specific characteristics: hierarchy of authority, impersonality, written rules of conduct, promotion based on achievement, specialized division of labor, and efficiency. This ultimate characteristic of Weberian bureaucracy, which states that bureaucracies are very efficient, is controversial and by no means accepted by all sociologists. There are certainly both positive and negative consequences to bureaucracy, and strong arguments for both the efficiency and inefficiency of bureaucracies. Weber's theory of bureaucracy says that it is extremely efficient, adding that bureaucracy is the most efficient form of organization. Also that bureaucracies are necessary to ensure the continued functioning of society, which has become drastically more modern and complex in the past century. To him, without the structured organization of bureaucracy, the complex society would be much worse off, due to the fact that society would act in an inefficient and wasteful way. He saw bureaucracies as organizations driven towards certain goals, which they could carry out efficiently. In addition, within an organization that operates under bureaucratic standards, the members will be better off due to the heavy regulation and detailed structure. Not only does bureaucracy make it much more difficult for arbitrary and unfair personal favours to be carried out, it also means that promotions and hiring will generally be done completely by merit.

The Scientific Management theory was introduced by Frederick Winslow Taylor to foster production efficiency and effectiveness. Taylor argues that inefficiencies could be tamed 
through managing production as a science. The scientific management view deals with the concept of planning of activities to gain efficiency, standardization, specialization and simplification. For productivity to be increased then there has to be mutual trust between management and workers. Taylor (1947) identified four principles of scientific management which includes: Taylor identifies four inherent principles of the scientific management theory, Science, not rule-of-thumb; Scientific selection of the worker, Management and labour cooperation rather than conflict; and Scientific training of workers.

\section{Research Design}

The study used survey research design; it used quantitative design and applied mono method which brought about our numerical data generated from questionnaire administered. It sought information from respondents on (effects of organizational structure on organizational performance).

\section{Population of the study}

The population of this study comprises of all staff of Covenant Micro Finance Bank as well as the customers of the banks. Employees are 51 and customers are 2600, which makes the population a total of 2651 .

\section{Sample Size}

The total population of this study comprises of both 51 employees and 2600 customers, which makes a total of 2651 population.

The YaroYemeni Formula is given as

$\mathrm{n}=\frac{N}{1+N(e)^{2}}$

where $\mathrm{n}=$ Sample Size, N= Population e=Level of Significance

$$
\begin{aligned}
& \mathrm{n}=\frac{N}{1+N(0.05)^{2}} \\
& \mathrm{n}=\frac{2651}{1+2651(0.05)^{2}} \\
& \mathrm{n}=\frac{2651}{1+2651(0.0025)} \\
& \mathrm{n}=\frac{2651}{1+6.5} \\
& \mathrm{n}=\frac{2651}{7.5}
\end{aligned}
$$


$\mathrm{n}=354$ Population

Therefore the total sum of 354 sample size comprising of both employees and customers of Covenant Micro Finance Bank will be the purposively sample for this study which was arrived at using Yaro Yemeni's formula as shown above.

\section{Sampling Technique}

This study used census method which takes the whole population of employee of Covenant Micro Finance Bank to be 51 and used sampling of 303 customers for convenience sake.

\section{Sources of Data}

The study adopted primary data, which was collected from Covenant Micro Finance Bank through the use of questionnaire distribution that would be shared to all employees of Covenant Micro Finance Bank Ltd, Canaan land, Ota, Ogun State.

\section{Validity/ Reliability Test}

In testing the validity of the research, content validity test was adapted. This type ensures that every instrument of research is sufficient for the study. Therefore, questionnaire used was well correlated with the objectives of study. This means that each objective and item reviewed is important to the study.

To test for reliability, Cronbach's alpha coefficient was is. When calculated, Cronbach's Alpha coefficient is 0.679 for the 4 items analysed. This shows that these items have met the widely accepted score of 0.679 which indicates that the research instrument is reliable.

\section{Technique for Data Analysis}

In analyzing the data generated through the use of questionnaire, frequency tables and percentage was used to analyze section A of the questionnaire. Also, correlation coefficient was used as a tool to analyze relationship between two issues. The choice of correlation coefficient assisted in finding the relationship between organizational structures on organizational performance.

\section{Interpretation of Results}

A total of 354 questionnaires that were distributed, and 118 questionnaires consisting of $33.3 \%$ were returned while 236 questionnaire consisting of $66.7 \%$ were not returned. In other words questionnaires returned were from 81 customers and 37 from employees making a total sum of 118 questionnaire that was answered. The table shows summary of parameters used and result displayed indicate percentage of strongly agreed, agreed, not sure, disagreed, strongly disagreed.

Key: $1=$ Strongly agree $\quad 2=$ Agree $\quad 3=$ Not sure $4=$ strongly disagreed 
Vol.5, No.6, pp.46-62, December 2017 Published by European Centre for Research Training and Development UK (www.eajournals.org)

\begin{tabular}{|c|c|c|c|c|c|}
\hline Statements & $1(\%)$ & $2(\%)$ & $3(\%)$ & $4(\%)$ & Analysis of data \\
\hline $\begin{array}{l}\text { Your } \\
\text { organization } \\
\text { instructs you on } \\
\text { what you can do } \\
\text { and cannot do }\end{array}$ & $\begin{array}{l}13(3 \\
5)\end{array}$ & $\begin{array}{l}15(4 \\
1)\end{array}$ & $4(11)$ & $5(14)$ & $\begin{array}{l}\text { Correlation is significant at the } 0.05 \text { level } \\
\text { (2-tailed). }\end{array}$ \\
\hline $\begin{array}{l}\text { Everything in } \\
\text { your organization } \\
\text { is strictly done } \\
\text { according to laid } \\
\text { down standard, } \\
\text { rules and } \\
\text { procedure in your } \\
\text { organization }\end{array}$ & $\begin{array}{l}16(4 \\
3)\end{array}$ & $\begin{array}{l}14(3 \\
8)\end{array}$ & $4(11)$ & $3(8)$ & $\begin{array}{l}\text { Correlation is significant at the } 0.05 \text { level } \\
\text { (2-tailed). }\end{array}$ \\
\hline $\begin{array}{l}\text { Formalization of } \\
\text { work process } \\
\text { enhances your } \\
\text { organization } \\
\text { performance }\end{array}$ & $\begin{array}{l}13(3 \\
5)\end{array}$ & $\begin{array}{l}15(4 \\
1)\end{array}$ & $6(16)$ & $2(5)$ & $\begin{array}{l}\text { Correlation is significant at the } 0.05 \text { level } \\
\text { (2-tailed). }\end{array}$ \\
\hline $\begin{array}{l}\text { As an employee } \\
\text { of this } \\
\text { organization you } \\
\text { are left to do as } \\
\text { you please }\end{array}$ & $\begin{array}{l}2(5.4 \\
)\end{array}$ & $\begin{array}{l}3(8.1 \\
)\end{array}$ & $\begin{array}{l}6(16 . \\
2)\end{array}$ & $\begin{array}{l}\text { 26(70 } \\
.3)\end{array}$ & $\begin{array}{l}\text { Correlation is significant at the } 0.05 \text { level } \\
\text { (2-tailed). }\end{array}$ \\
\hline $\begin{array}{l}\text { As an employee } \\
\text { of } \\
\text { organization I } \\
\text { have to ask my } \\
\text { immediate } \\
\text { manager before I } \\
\text { Do almost } \\
\text { anything. }\end{array}$ & $5(14)$ & 7(19) & 7(19) & $\begin{array}{l}18(49 \\
)\end{array}$ & $\begin{array}{l}\text { Correlation is significant at the } 0.05 \text { level } \\
\text { (2-tailed). }\end{array}$ \\
\hline $\begin{array}{l}\text { Only top } \\
\text { managers make } \\
\text { decisions } \\
\text { regarding } \\
\text { operations in my } \\
\text { organization }\end{array}$ & $9(24)$ & $\begin{array}{l}16(4 \\
3)\end{array}$ & $8(22)$ & $4(10)$ & $\begin{array}{l}\text { Correlation is significant at the } 0.05 \text { level } \\
\text { (2-tailed). }\end{array}$ \\
\hline $\begin{array}{l}\text { As an employee } \\
\text { of } \\
\text { organization any } \\
\text { decision I make } \\
\text { must have my } \\
\text { immediate }\end{array}$ & $\begin{array}{l}6(16 . \\
2)\end{array}$ & $\begin{array}{l}17(4 \\
5.9)\end{array}$ & $\begin{array}{l}\text { 9(24. } \\
\text { 3) }\end{array}$ & $\begin{array}{l}5(13 . \\
5)\end{array}$ & $\begin{array}{l}\text { Correlation is significant at the } 0.05 \text { level } \\
\text { (2-tailed). }\end{array}$ \\
\hline
\end{tabular}


Vol.5, No.6, pp.46-62, December 2017

Published by European Centre for Research Training and Development UK (www.eajournals.org)

\begin{tabular}{|c|c|c|c|c|c|}
\hline $\begin{array}{l}\text { manager's } \\
\text { approval }\end{array}$ & & & & & \\
\hline $\begin{array}{l}\text { As an employee } \\
\text { of this } \\
\text { organization, my } \\
\text { duties must be } \\
\text { approved before } \\
\text { it is performed. }\end{array}$ & $\begin{array}{l}7(18 . \\
9)\end{array}$ & $\begin{array}{l}17(4 \\
5.9)\end{array}$ & $\begin{array}{l}6(16 . \\
2)\end{array}$ & $\begin{array}{l}7(18 . \\
9\end{array}$ & $\begin{array}{l}\text { Correlation is significant at the } 0.05 \text { level } \\
\text { (2-tailed). }\end{array}$ \\
\hline $\begin{array}{l}\text { Your } \\
\text { organization has } \\
\text { consistent } \\
\text { increase in } \\
\text { organizational } \\
\text { profits } \\
\end{array}$ & $\begin{array}{l}10(2 \\
7.0)\end{array}$ & $\begin{array}{l}17(4 \\
5.9)\end{array}$ & $\begin{array}{l}7(18 . \\
9)\end{array}$ & 3(7.9) & $\begin{array}{l}\text { Correlation is significant at the } 0.05 \text { level } \\
\text { (2-tailed). }\end{array}$ \\
\hline $\begin{array}{l}\text { Your } \\
\text { organization is } \\
\text { satisfied with the } \\
\text { profit attain } \\
\text { annually }\end{array}$ & $\begin{array}{l}7(18 . \\
9)\end{array}$ & $\begin{array}{l}11(2 \\
9.7)\end{array}$ & $\begin{array}{l}9(24 . \\
3)\end{array}$ & $\begin{array}{l}\text { 10(27 } \\
.0)\end{array}$ & $\begin{array}{l}\text { Correlation is significant at the } 0.05 \text { level } \\
\text { (2-tailed). }\end{array}$ \\
\hline $\begin{array}{l}\text { This organization } \\
\text { offers you good } \\
\text { service of high } \\
\text { value } \\
\text { minimum cost }\end{array}$ & $4(49)$ & $\begin{array}{l}18(2 \\
2.2)\end{array}$ & $\begin{array}{l}29(3 \\
5.8)\end{array}$ & $\begin{array}{l}\text { 19(37 } \\
.1)\end{array}$ & $\begin{array}{l}\text { Correlation is significant at the } 0.05 \text { level } \\
\text { (2-tailed). }\end{array}$ \\
\hline $\begin{array}{l}\text { As a customer of } \\
\text { this organization } \\
\text { I am satisfied } \\
\text { with the way } \\
\text { work is done here }\end{array}$ & $7(9)$ & $\begin{array}{l}\text { 19(2 } \\
\text { 4) }\end{array}$ & $\begin{array}{l}\text { 27(3 } \\
\text { 3) }\end{array}$ & $\begin{array}{l}28(34 \\
)\end{array}$ & $\begin{array}{l}\text { Correlation is significant at the } 0.05 \text { level } \\
\text { (2-tailed). }\end{array}$ \\
\hline $\begin{array}{l}\text { As a customer of } \\
\text { this organization } \\
\text { I am always } \\
\text { attended to on } \\
\text { time whenever I } \\
\text { approach the } \\
\text { organization }\end{array}$ & $6(7)$ & $\begin{array}{l}\text { 20(2 } \\
5)\end{array}$ & $\begin{array}{l}29(3 \\
6)\end{array}$ & $\begin{array}{l}26(32 \\
)\end{array}$ & $\begin{array}{l}\text { Correlation is significant at the } 0.05 \text { level } \\
\text { (2-tailed). }\end{array}$ \\
\hline $\begin{array}{l}\text { I prefer } \\
\text { services of the } \\
\text { organization to } \\
\text { any order } \\
\text { organization } \\
\end{array}$ & $6(7)$ & $\begin{array}{l}\text { 18(2 } \\
\text { 2) }\end{array}$ & $\begin{array}{l}30(3 \\
7)\end{array}$ & $\begin{array}{l}27(34 \\
)\end{array}$ & $\begin{array}{l}\text { Correlation is significant at the } 0.05 \text { level } \\
\text { (2-tailed). }\end{array}$ \\
\hline
\end{tabular}




\section{TEST OF HYPOTHESIS AND DISCUSSION OF RESULTS}

The hypothesis were tested using the Pearson product moment correlation for hypothesis land 2 , and 3 and 4.

\section{Hypothesis 1}

$\mathrm{H}_{0}$ There is no relationship between organizational centralization and organizational customer satisfaction. The Pearson correlation $(\mathrm{r}=0.351)$ shows that there is a weak positive relationship between centralization and customer satisfaction. Therefore $r^{2}=0.123$ means that the independent variable employed (centralization) was only able to explain about $12.3 \%$ of the variations in the dependent variable (customer satisfaction). Thus, organizational centralization has $12.3 \%$ effects on organizational customer satisfaction. Using the 2 tailed tests since $\mathrm{p}$ is less than our preset level of significance 0.05 i.e. $\mathrm{P}=0.033$ is less than 0.05 , Indicates the correlation between organizational centralization and organizational customer satisfaction is statistically significant therefore we reject $\mathrm{H}_{0}$ There is no relationship between organizational centralization and organizational customer satisfaction and accept the $\mathrm{H}_{1}$ There is relationship between organizational centralization and organizational customer satisfaction. This implies that there is positive relationship.

\section{Hypothesis 2}

$\mathrm{H}_{0}$ There is no relationship between organizational centralization and organizational profit.

The Pearson correlation table 4.3.2 states that $r=0.55$ this shows that there no significant relationship between organizational centralization and organizational profit. Therefore $r^{2}=$ 0.3025 this means that the independent variable employed (organizational formalization) was only able to explain about $30 \%$ of the variations in the dependent variable (organizational customer satisfaction). This means that organizational formalization has $30 \%$ effects on organizational customer satisfaction. Using the 2 tailed tests since $\mathrm{p}$ is less than our preset level of significance 0.05 i.e. $\mathrm{P}=0.746$ is greater than 0.05 , Indicating that the correlation between organizational centralization and organizational profit is not statistically significant therefore accept $\mathrm{H}_{0}$ There is no relationship between organizational centralization and organizational profit and reject $\mathrm{H}_{1}$ There is relationship between organizational centralization and organizational profit. Implying that there is no relationship.

\section{Hypothesis 3}

$\mathrm{H}_{0}$ There is no relationship between organizational formalization and organizational customer satisfaction.

The Pearson correlation table 4.3 .3 above $r=0.006$ this shows that there no significant relationship between organizational formalization and organizational customer satisfaction. Therefore $r^{2}=0.000036$ this means that the independent variable employed (organizational formalization) was only able to explain about $0.0036 \%$ of the variations in the dependent variable (organizational customer satisfaction). This means that organizational formalization has $0.0036 \%$ effects on organizational customer satisfaction. Using the 2 tailed tests since $\mathrm{p}$ is less than our preset level of significance 0.05 i.e. $\mathrm{P}=0.971$ is greater than 0.05 , Indicating that the correlation between organizational formalization and customer satisfaction is not 
statistically significant therefore accept $\mathrm{H}_{0}$ There is no relationship between organizational formalization and organizational customer satisfaction and reject $\mathrm{H}_{1}$ There is relationship between organizational formalization and organizational customer satisfaction. Implying that there is no relationship.

\section{Hypothesis 4}

$\mathrm{H}_{0}$ There is no relationship between organizational formalization and organizational profit.

The Pearson correlation table 4.3 .4 above $r=-0.200$ this shows that there no significant relationship between organizational formalization and organizational profit. Therefore $r^{2}=-$ 0.04 this means that the independent variable employed (organizational formalization) was only able to explain about $-4 \%$ of the variations in the dependent variable (organizational profit). This means that organizational formalization has $-4 \%$ effects on organizational profit. Using the 2 tailed tests since $\mathrm{p}$ is less than the present level of significance 0.05 i.e. $\mathrm{P}=0.236$ is greater than 0.05 , Indicating that the correlation between organizational formalization and organizational profit is not statistically significant therefore accept $\mathrm{H}_{0}$ There is no relationship between organizational formalization and organizational profit and reject $\mathrm{H}_{1}$ There is relationship between organizational formalization and organizational profit. Implying that there is no relationship.

\section{THEORETICAL FINDINGS}

This study notes that as organizations are being formed over time, it has given rise to studies and development of theories or principles that will govern the establishment of organizations as well as the structure inside it. Furthermore this study has found out that the theories as related to organizations include Bureaucracy, Rationalization (Scientific Management), and the Division of Labor. As organizations are implemented over time, many people experimented as to which one was best. But each theory provides distinct advantages and disadvantages when implemented. Further findings of this study reveal that the management of the modern office is based upon written rule, and rules that are stable and can be learned. This means that most modern organizations operate with some form of formalization which everyone in the organization must follow.

Another finding of this study is that the perspective of Rational System shows that specificity of goals and formalization are very crucial to an organization. Goal specification provides guidelines for specific tasks to be completed along with a regulated way for resources to be allocated. Formalization is a way to standardize organizational behavior and stable expectations. Standardization of work which is brought about by formalization may not be a perfect tool all the time for employee's performance. For instance in the theory of scientific management, problems arose and one of them is that standardization leads workers to rebel against the mundane. Another is that workers may reject the incentive system because they are required to constantly work at their optimum level, an expectation that may be unrealistic. Doing the same routines may not be for everyone. Also, employees were not familiar with other parts of the job. They couldn't assist employers of different parts of the system. 
One other finding of this study is that organizational structure follows some laws and they must be functional under the rules of those laws. These laws govern the modern organizations and lead them in the direction that will maximize profits efficiently. Thus, the modernity of organizations is to generate maximum profit, Further findings is that Max Weber believed that an ideal bureaucracy consists of six specific characteristics: hierarchy of authority, impersonality, written rules of conduct, promotion based on achievement, specialized division of labor, and efficiency. So therefore any organization running an idea bureaucracy that organization must consist of six specific characteristics. Also this study further find's that the hierarchical nature of bureaucracies allows employees to demonstrate achieved social status when an office holder is elected instead of appointed, that person is no longer a purely bureaucratic figure.

\section{RECOMMENDATIONS}

The study recommends that management of organizations use decentralization as a dimension of organizational structure to restructure their organization when centralization is not giving required organizational performance. Perhaps this way they may attain strong positive relationship between decentralization and customers satisfaction and also between decentralization and organizational profit etc. Since using organization centralization brings about a weak positive relationship on their organizational customer satisfaction, and no significant relationship on profit. Also, seeing organizational formalization does not have any significant relationship with both customers satisfaction and profit of the organization, it is recommended that management of the organization adjust the way things are formalized by reducing the way work are standardized in the organization so as to increase the performance of the organization. So therefore in order to avoid all this problems that scientific management had, it will be good to make the organization less formal allowing employee to have the freedom to get job done efficiently and increase organization performance through whatever means known to the employees of the organization.

\section{CONCLUSION}

This research has shown that one of the null hypothesis was rejected because there is a relationship between organizational centralization (independent variable) and organizational customer satisfaction (dependent variable) but this relationship is a weak positive one, therefore the results means the two variables do not complement each other so well. This study has therefore recommended that another organizational dimension should be look into for organizational performance to increase. And concerning the rest null hypothesis such as; $\mathrm{H}_{0}$ There is no relationship between organizational centralization and organizational profit.

$\mathrm{H}_{0}$ There is no relationship between organizational formalization and organizational customer satisfaction.

$\mathrm{H}_{0}$ There is no relationship between organizational formalization and organizational profit. were accepted and the alternative hypothesis was rejected. And therefore the above 1-3 hypothesis do not play any important role in organizational performance. 


\section{REFERENCE}

Adsit, J.D., London, M., Crom, S. \& Jones, D. (1996). Relationships between employee attitudes.

Akande. O. O and Ojokuku R. M,, (2008), Basic principle of management a text for management, published by apex books limited. Pg8

Ambro M. Praprotnik M. (2008) Organisational Effectiveness And Customer Satisfaction, Organizacija, Vol. 41, No 5.

Armstrong G, Kotler P. (2009). Marketing: An Introduction Prentice-Hall. N.J, 5th ed. Black S.E. and Lynch L. M. (2000), What's Driving the new Economy: The Benefits of Work Place Innovation. NBER working paper pg74-79.

Chegini M. G, Yousefi .S And Rastad .S, (2013) Competitive Study Of Effects About Dimensions Of Organizational Structure On Productivity, Journal Of Basic And Applied Scientific Research, Text road Publication, ISBN 2090-4304. Pg318-326

Csaszar, Stephen M., Arbor A and Michigan, (2012) Organizational Structure as A Determinant of Performance: Evidence from Mutual Funds, U.S.A, Published Online Early view In Wiley Online Library (Wileyonlinelibrary.Com).

David Lewis, (1988) Basics of Business Pitman Publishing 128 Long Acre, London Wc2e 9an, Pg 82.

Davis,J.H., Schoorman,F.D.,Mayer,R.C.,\&Tan,H.H.(2000). The Trusted General Manager and Business Unit Performance: Empirical Evidence of a Competitive Advantage. Strategic Management Journal, 21,563-576.

Dehkordi F. L. (2009). "Strategic Management", Payam Noor University, Tehran.

Duncan, R. (1979). "what is the Right Organizational Design?" Organizational Dynamics"

Edmand M. R. (1987), Macroeconomics: Theory and Policy. Prentice-Hall Third Edition Englewood Cliffs, New Jersy, Inc 07632.

Enikanselu S. A. and Oyende A. I, (2009) Essentials of Management, Olas Ventures, Nigeria. Pg 137,138,140-163

Fornell C. (2008), Clienti soddisfatti. Vincitori e vinti nella battaglia per le preferenze dei consumatori, Franco Angeli, Milano.

Gary Dessler, (2004) Management Principle and Practices for Tomorrow's Leaders, Pearson Education, Inc, Upper Saddle River, New Jersey. Pg154.

Gerpott,T. J., Rams,W., \& Schindler, A. (2001) Customer retention, loyalty, and satisfaction in the German mobile cellular telecommunications market Telecommunications Policy, Vol 25, 249-269.

Goba N. (2001), A Vital Link to Building Competitive Organizations. Productivity SA.

Golinowska M and Kruszyński M (2013) Organization Structure in Relation to The System of Integrated Production in Farms, University of Life Sciences In Wrocław, Poland.

Guo, L., Xiao, J. J., \& Tang, C. (2009). Understanding the psychological process underlying customer satisfaction and retention in a relational service. Journal of Business Research, 62, 1152.1159.

Ismael Y. A., Nor'Aini Y. , Davoud N, (2010) A Review Paper on Organizational Culture and Organizational Performance, International Journal of Business and Social Science Vol. 1 No. 3. 
Jones, G.R. et, al (2000). Contemporary Management. USA: The McGraw-Hill Companies, Inc

Karunaratne .W. M. K. K. And. Jayawardena L. N. A. C (2010) Assessment Of Customer Satisfaction, A Case Study in A Five Star Hotel, Tropical Agricultural Research Vol. 21(3) pg $258-265$

Katsikea E, Theodosiou M, Perdikis N and Kehagias J (2011) The Effects of Organizational Structure and Job Characteristics on Export Sales Managers' Job Satisfaction and Organizational Commitment, Journal of World Business, Vol 46, Pg 228-233.

Keiningham, T.L., Perkins-Munn, T., Aksoy, L. and Estrin D. (2005). Does customer satisfaction lead to profitability?. Managing Service Quality. Vol. 15 No. 2, pp. 172181.

Lin, J. S. C., \& Wu, C. Y., (2011). The role of expected future use in relationship-based service retention. Managing Service Quality, 21(5), pg 535-551.

Malema W. (2011) Productivity Dynamics in the south African economy: A review of literature, International management of finance and operations management, vol 1. No 1.

Mehring J. (2004) 'what is lifting Productivity' Business Week, Pg. 32.

Microsoft Corporation, (2009) Encarta Dictionary, U.S.A. Encwish@ Microsoft.Com

Mohammad .M B. And Shahzad K, (2012) Attaining Customer Loyalty! The Role of Consumer Attitude and Consumer Behavior, International Review of Management And Business Research Vol. 1 Issue.1

Mohammad T., Shaeir B., Shahram G., Seyed A. B. And Seyyed J. M., (2011) The Relationship Between Customer Satisfaction And Relationship Marketing Benefits, Arabian Journal Of Business And Management Review Vol. 1, No.3

Mousavi S. M, Jadidi R and Javanmard H, (2013) A Study on Effects of Organizational Structure on Performance of Research Organizations, Management Science Letters 3, Pg 699-704

Naveed Y, (2010) Organizational Democracy and Organization Structure Link:Role of Straytegic Leadership and Environmental Uncertainty, Business Review Vol 5 No 2.

Olorunke.K and Akinyele S.T. An Empirical Analysis of Internal Marketing on Organizational Commitment: A Study of Banks In Lagos-Nigeria, by, www. Google.com (accessed May, 2014)

Olusola O. A and Ojokuku R. M, (2008) Basic principle of management a text for management, published by apex books limited. Pg8

Omachonu V. K. and Ross J. E. (1994) Principles of Total Quality, Delray Beach; St Lucie Press Pg. 190.

Owolabi Y. L. and Kingsley C. C. (2007), Evaluation of leadership and Organizational Performance in Small Scale industries in Nigeria; A Case of Selected Small Scale industries, Blekinge Institute of Technology, Master's Thesis, pg 9 Sweden.

Parsons, J. (1999), Productivity Means Plenty for Everyone. Productivity SA May/June 1999.

Patricia Fernando and Chandrabanu Samaraweera, (2006) Sterling Dictionary Of Business Terms, 4, $1^{\text {st }}$ Edition, Sterling Publishers (P) Ltd, ISBN 812072940 New Delhi.

Rajaeepour S, Azizollah. A, Mahmoud Z. and Shokouhi. S. (2012) Relationship between organizational structure and organizational alienation. Interdisciplinary Journal of Contemporary Research In Business Vol 3, No 12. Pg 188-196 
Robbins, S.P. (2005) organizational behavior, $11^{\text {th }}$ edition, new delhi, prentice-hall.

Robbins,Stephen, (2000) Organizational theory, Structure, design and applications, Persian translate Seyed Mehdi Alvani \& Hasan Danaei Fard, Saffar publications.

Robert W. R, Orville C. Walker, Jr., and Kenneth J. Roering (1985) The Organization of Marketing Activities: A Contingency Theory Of Structure And Performance, Journal Of Marketing, Vol. 49, Pg 13-25.

Robey D, Bakr M. M. And Miller T. S. (1977) Organizational Size and Management Autonomy: Some Structural Discontinuities, Academy of Management Journal Vol. 20, No. 3, U.S.A, 378-397.

Robinson, Richard B. Jr. (1982). The Importance of "Outsiders" in Small Firm Strategic Planning. Academy of Management Journal, Vol.25 (1): pg80-93.

Shafaee.J, Rahnama A. Alaei A and Jasour J. (2012) Evaluation Of The Impact Of Organizational Structure And Job Characteristics On Job Satisfaction And Organizational Commitment Case Study: Islamic Azad University, Parsabad Branch, Journal Of Basic And Applied Scientific Research, ISBN 2090-4304, Iran. Pg23292335

Shahzad k. and Faryal N. (2012)" Factors affecting buying behavior of females for purchase of cosmetics" International review of business and social sciences vol. 1, no. 9, 6876.

Steindel C. and Stiroh K.J. (2001), productivity: What is it, and Why do we care about it?

Stiroh K. J. (2001), What Drives Productivity Growth? FRBNY Economic Policy Review.

Sunday Oyewole Otokiti, (2010) Contemporary Issues and Controversy in Research Methodology, Management Review Ltd, ISBN-978-044-8-05-5, Nigeria.

Teixeira, R., Koufteros, X. A., Peng, X. D (2012) Organizational Structure, Integration, and Manufacturing Performance: A Conceptual Model And Propositions, Journal of Operations and Supply Chain Management 5 (1), ISSN: 1984-3046, Pg 69 - 81.

Ubani E.C, (2012) Evaluating The Effects of Organizational Structure on Theeffective Delivery of Civil Engineering Projects, Vol 4(6) Interdisciplinary Journal of Contemporary Research In Business, Nigeria. Pg 1290

Zani S. Berzieri L. (2008) Measuring Customer Satisfaction Using Ordinal Variables: $A n$ Application In A Survey on A Contact Center Statistica Applicata, Vol. 20, N. 3-4, $\operatorname{Pg} 331$ 